\title{
Symulacyjna analiza efektywności nastawy hamulca „długa lokomotywa”
}

\begin{abstract}
$W$ artykule przedstawiono wybrane rezultaty symulacyjnej metody analizy układu hamulcowego pociagu dla nowo wprowadzonej w Polsce nastawy hamulca pociagów towarowych o nazwie ,dtuga lokomotywa” Zaprezentowano wptyw tego nastawienia na drogę hamowania składu pociagu oraz na występujace w pociagu sily wzdlużne.
\end{abstract}

\section{Wstęp}

Nastawy hamulca „towarowy” i ,osobowy” wykorzystywane są w praktyce kolejowej od wielu dziesiątków lat, różnią się one czasem napełniania cylindrów hamulcowych. Dodatkowo dla hamowania standardowych pociaggów osobowych większych prędkości wprowadzono nastawę R, która posiada zwiększona, w porównaniu z nastawą „osobowy” intensywność hamowania. Nastawy te sa jednolite dla wszystkich pojazdów składu pociagu. W 2009 r. do instrukcji eksploatacji hamulców pociagów towarowych przewoźnika CARGO wprowadzono nową nastawę o nazwie "długa lokomotywa". Prezentowany artykuł dotyczy rozpatrzenia symulacyjnego wpływu ten nastawy na właściwości hamowanego składu pociagu.

\section{Metoda analiz}

Analiz wpływu nastawienia „długa lokomotywa” dokonano przy pomocy własnej metody symulacyjnej składającej się z kilku części składowych całej symulacji:

- przepływów w przewodzie głównym,

- pracy zaworów hamulcowych i cylindrów hamulcowych,

- charakterystyk ciernych hamulca,

- dynamiki wzdłużnej pociagu obejmującej hamowność pociagu oraz analizy:

sił wzdłużnych występujących w modelu pociągu sztywnego

sił wzdłużnych występujących wzdłuż pociagu podatnego.

Opis modelu począwszy od przewodu głównego aż po dynamikę pociagu sztywnego został opisany $\mathrm{w}[1$, 2] ze szczególnym uwzględnieniem zjawisk pneumatycznych i zweryfikowany w $[1,3]$. Bardziej szczegółowe rozpatrzenie współczynnika tarcia par ciernych i problem sił wzdłużnych w pociagu podatnym zostały rozwinięte w ostatnich pracach.

Metodę wykorzystującą pomiary doświadczalne zjawisk pneumatycznych $\mathrm{w}$ hamulcu połączoną $\mathrm{z}$ symulacją komputerową sił wzdłużnych przedstawiono $\mathrm{w}[4,5]$.
Analiza sił wzdłużnych jest zjawiskiem bardzo skomplikowanym, gdyż zależy od rodzaju zderzaków (w wagonach może wystapić kilka bardzo różnorodnych typów zderzaków w różnorodnych wykonaniach), od amortyzatorów urządzeń pociagowych (także występuje kilka typów), od wielkości luzu w urządzeniach pociagowo zderznych i w przypadku hamulca klockowego bardzo znacznie od prędkości początku hamowania. Wpływ tak wielu czynników budowy pociagu może powodować, że ogólny wpływ czynnika hamulcowego może być mniej uchwytny. Z tego względu rozwinieto również metodę analizy sił wzdłużnych $\mathrm{w}$ pociagu sztywnym. Jest to metoda prostsza, dająca wyniki mogące odbiegać od rzeczywistych w pociagu podatnym. Jednak jej użyteczność dla badacza analityka, zdaniem autora, jest znaczna, gdyż może być punktem wyjściowym do analizy wpływu pneumatyki hamulca na siły wzdłużne w pociagu, by dopiero w kolejnym etapie przejść do analizy urządzeń pociagowo-zderznych, a na końcu do oceny bezpieczeństwa ruchu.

\section{Nastawienie „dluga lokomotywa”}

Pojęcie „długiej lokomotywy” nie oznacza fizycznie lokomotywy, tylko opisuje specyficzne nastawienie hamulca pociagu, w którym lokomotywa i pierwsze pięć wagonów posiadają nastawienie hamulca „towarowy” a reszta wagonów posiada nastawienie hamulca „osobowy”. Nie jest to sposób prowadzenia specyficzny dla Polski, inne zarządy kolejowe wprowadziły już wcześniej tę nastawę eksploatacyjną. Była ona rozpatrywana w pracach $\mathrm{w}$ ramach Raportów i Technicznych Dokumentów UIC (wcześniej Raportów ERRI) B 177 i B 177.1. Brak analiz tego tematu w Polsce skłonił autora do krótkiego przedstawienia omawianego zagadnienia.

Od 2010 r. wg. Instrukcji[6] PKP CARGO obowiązują zmiany (przedstawione poniżej ze znacznymi skrótami): 
1. W pociagach towarowych stosuje sie zasadniczo nastawienie hamulców P (osobowy), o ile spetnione sq warunki podane w ust. 2 i 3. Jeśli choćby jeden $z$ warunków nie jest spetniony, we wszystkich pojazdach pociagu hamulce musza być nastawione na $G$ (towarowy). Nastawienie G należy stosować również zawsze wtedy, gdy rozklad jazdy podaje takie nastawienie.

2. Dtugość składu pociagu, w którym stosuje sie nastawienie hamulców $P$, nie może być większa niż $700 \mathrm{~m}$.

3. Jeśli pociag spetnia warunek podany $w$ ust. $2 i$ ma kursować z nastawieniem hamulców $P$, to $w$ zależności od masy składu pociagu oraz zestawienia sktadu pociagu należy stosować nastawienia hamulców jak w poniższej tabeli:

\begin{tabular}{|c|c|c|c|}
\hline l.p. & $\begin{array}{r}\text { Masa } \\
\text { składu } \\
\text { pociągu }\end{array}$ & $\begin{array}{l}\text { Nastawienie } \\
\text { hamulców }\end{array}$ & Zestawienie składu pociągu \\
\hline 1 & $<800 \mathrm{t}$ & wszystkie P & Dowolne \\
\hline 2 & $\begin{array}{l}>800 \mathrm{t} \mathrm{i} \\
<1200 \mathrm{t}\end{array}$ & wszystkie P & $\begin{array}{c}\text { Dowolne, } z \text { zachowaniem innych } \\
\text { przepisów niniejszej instrukcji }\end{array}$ \\
\hline 3 & $\begin{array}{r}>1200 \mathrm{t} \mathrm{i} \\
<1600 \mathrm{t}\end{array}$ & $\begin{array}{l}\quad \text { pierwsze } 5 \\
\text { wagonów - } \\
\mathrm{G}^{*} \text {, pozostałe } \\
\text { wagony - } \mathrm{P} \\
\text { (,,długa lo- }\end{array}$ & $\begin{array}{l}\text { Jeśli wśród pierwszych } 5 \text { wagonów jest } \\
\text { wagon wieloczłonowy co najmniej 4- } \\
\text { osiowy lub wagony (albo inne pojazdy) } \\
\text { na stałe sprzęgnięte co najmniej 4-osiowe } \\
\text { - należy liczyć każdy człon jak jeden } \\
\text { wagon z hamulcem nastawionym na G }\end{array}$ \\
\hline 4 & $\begin{array}{l}>1600 \mathrm{t} \\
\mathrm{i}<2500 \mathrm{t}\end{array}$ & komotywa") & $\begin{array}{l}\text { W składzie pociągu nie może być żad- } \\
\text { nych pojazdów wieloczłonowych lub na } \\
\text { stałe sprzęgniętych pojazdów. W składzie } \\
\text { pociągu nie może być żadnego wagonu } \\
\text { lub innego pojazdu o masie całkowitej } \\
\text { mniejszej niż } 32 \mathrm{t}\end{array}$ \\
\hline 5 & $\begin{array}{r}>2500 \mathrm{t} \mathrm{i} \\
<4000 \mathrm{t}\end{array}$ & & $\begin{array}{l}\text { W składzie pociągu nie może być żad- } \\
\text { nych pojazdów wieloczłonowych lub na } \\
\text { stałe sprzęgniętych pojazdów } \\
\text { W składzie pociągu nie może być żadne- } \\
\text { go wagonu lub innego pojazdu o masie } \\
\text { całkowitej mniejszej niż } 40 \text { t }\end{array}$ \\
\hline
\end{tabular}

W przypadku zmiany czoła pociagu konieczne jest: dokonanie zmiany nastawienia hamulców w pierwszych pięciu i ostatnich pięciu wagonach i ponowne obliczenie masy hamującej pociagu".

Wprowadzenie tej Instrukcji powoduje pewne utrudnienia w pracy składania pociagu, ale cechuje się polepszeniem hamowności pociagów towarowych.

Sterowanie hamowaniem poprzez obniżenie ciśnienia $\mathrm{W}$ PG z powodu skończonej prędkości rozchodzenia się impulsu hamowania (granicą jest prędkość dźwięku) oporów przepływu powietrza i innych czynników jest mniej efektywne dla długich pociagów. W nastawieniu osobowym czas napełniania cylindra wynosi 3-5 s i jest ono stosowane przeważnie dla pociągów pasażerskich, a właściwiej dla pociagów krótkich ( do $400 \mathrm{~m}$ długości). W pociągach dłuższych napełnianie cylindrów hamulcowych jest wolniejsze by zapobiec zbytniemu zróżnicowaniu napełniania cylindrów wzdłuż pociagu, czas napełniania pojedynczego wagonu w nastawieniu ,towarowy” wynosi 18 - 30s.

Dwoma przeciwstawnymi kryteriami oceny hamowności pociagu jest droga hamowania i wartość maksymalnych sił wzdłużnych. W nastawieniu „towarowy” droga hamowania jest dłuższa, ale poziom sił wzdłużnych znacznie mniejszy. Wartość maksymalnych sił wzdłużnych nie jest możliwa do jednoznacznej oceny, gdyż zależy silnie od długości pociagu, rozłożenia ładunku, rodzaju okładzin ciernych, rodzaju i charakterystyki zderzaków i luzów międzywagonowych, a także od prędkości początku hamowania. Maksymalne siły wzdłużne występują dla niewielkich prędkości początku hamowania, rzędu $20-30 \mathrm{~km} / \mathrm{h}$, gdy nierównomierność wzrostu sił hamujących poszczególnych wagonów nakłada się w przypadku hamulca klockowego z klockami żeliwnymi ze wzrostem współczynnika tarcia dla małych prędkości jazdy. Natomiast wartość drogi hamowania ogranicza maksymalne prędkości jazdy, a każdym przypadku winno być możliwe uzyskanie jej minimalnej wartości. Pociąg może hamować z maksymalną intensywnością $\mathrm{Z}$ każdej prędkości początkowej i w związku z tym musi spełniać kryteria bezpieczeństwa dla każdej prędkości.

Nastawa „długa lokomotywa” wprowadzane na polskich szlakach kolejowych eliminuje częściowo duże zróżnicowanie czasów napełniania poszczególnych wagonów. W pierwszych wagonach długiego składu (wraz z lokomotywa) nastawienie hamulca jest „towarowy” zmniejszając początkową zbyt dużą intensywność hamowania tych początkowych wagonów w stosunku do reszty składu, a w reszcie składu nie następuje nadmierne osłabienie hamowności. W niniejszej pracy przedstawiono tylko fragmenty większych rozważań.

\section{Analizy nastawienia ,długa lokomotywa"}

Ze względu na wymagany rozmiar artykułu ograniczono się tylko do analizy hamulca klockowego $i$ jednej wybranej charakterystyki współczynnika tarcia.

Do analiz przyjęto wagony węglarki o długości 14,04 $\mathrm{m}$ o długości przewodu głównego 14,28 m (różnica długości jest spowodowana zagięciami PG pod wagonem) o przekroju 11/4" o masie na oś $20 t$ ,czyli całkowitej wagonu 80t. Przy 50 wagonach daje 
to długość składu ok. $702 \mathrm{~m}$ i mase $4000 \mathrm{t}$, czyli maksymalne wartości dla składu z długą lokomotywą. Pominięto dla przejrzystości nieistotną odmienność długości i masy lokomotywy od parametrów wagonu.

W układzie hamulcowym zastosowano najbardziej rozpowszechnione w Polsce: zawór maszynisty FV4a i zawory rozrządcze Est3f oraz cylindry hamulcowe 16". Zmienność współczynnika tarcia klocków hamulcowych przyjęto wg, funkcji na rys. 1 pomijając zmienność w funkcji nacisków i temperatury.

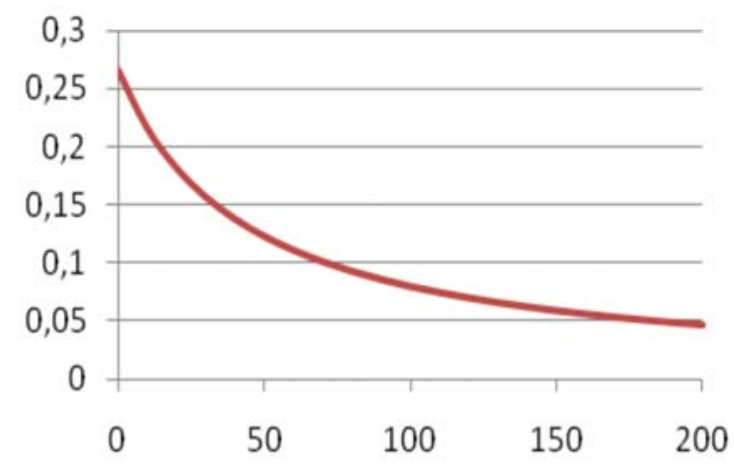

Rys1. Zmienność współczynnika tarcia klocka hamulcowego w funkcji prędkości $[\mathrm{km} / \mathrm{h}]$

Oprócz przewodu głównego z niewielkimi odgałęzieniami, traktowanego jako standardowy (odgałęzienie jest konieczne w przypadku dwóch końcówek PG na każdej czołownicy), przeanalizowano zastosowane długich odgałęzień spotykanych w praktyce, pogarszających hamowność pociagu.

W przypadku pociagu podatnego zastosowano zderzaki międzywagonowe ze sprężynami pierścieniowymi, bez napięcia wstępnego, z ok. 50\% pochłanianiem energii (rys.2).

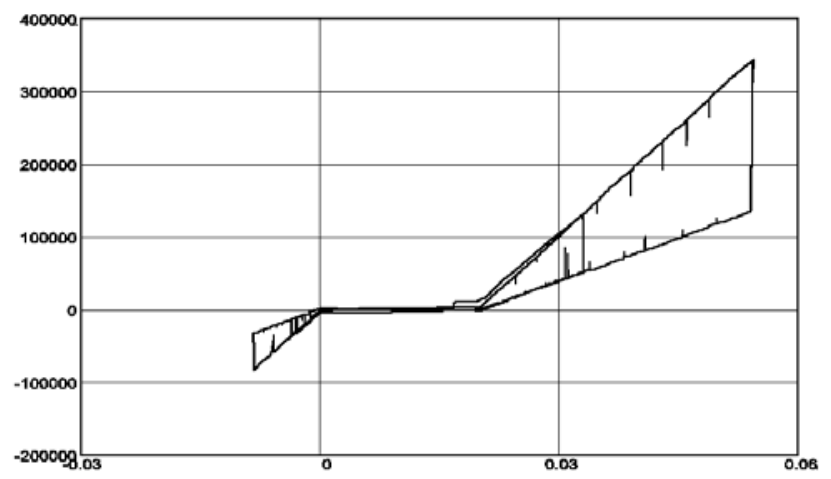

Rys. 2. Charakterystyka urządzenia pociągowo-zderznego między wagonami 15 i 16 uzyskana po symulacji

Dla wybranych wariantów składu dokonano również symulacji hamowania $\mathrm{z}$ luzami w zderzakach międzywagonowych o wartościach równych $0,02 \mathrm{~m}$. We współczesnych pociagach europejskich taki luz nie powinien wystąpić, symulację te przedstawiono dla wskazania możliwości pogorszenia właściwości pociagu.
Przykładowy przebieg symulacji przedstawiono na rys. 3 i 4 . Wszystkie warianty wyników zaprezentowano w tabeli 2 i 3 . Wyniki nr 1 i 2 w tabeli 2 przedstawiają hamowania pojedynczych wagonów ze 100 $\mathrm{km} / \mathrm{h}$. Widoczna jest różnica dróg hamowania ok. 200 m między nastawieniem hamulca ,osobowy” i ,towarowy". W reszcie tabeli 1przedstawiono wyniki symulacji różnych nastaw pociągu 700m, 4000t (graniczna wielkość składu z nastawą „długa lokomotywa”). Różne czasy napełniania cylindrów przedstawiono $\mathrm{W}$ poz. 3, 4, i 5 .

Charakterystyczne dla nastawienia „długa lokomotywa" jest, że spowolnienie napełniania cylindrów pierwszych pojazdów powoduje powstania chwilowych sił wzdłużnych rozciagających (oznaczonych znakiem ujemnym), co w bilansie całego przebiegu sił wzdłużnych powoduje, że przednia część długości pociagu nie wywołuje powstania nadmiernych sił wzdłużnych.

W pociagu długim (np. ponad 700 m długości) opóźnienie napełniania cylindrów końca pociągu jest większe i efekt skrócenia drogi hamowania w nastawieniu „długa lokomotywa” jest mniejszy.

Przeanalizowano również skład pociągu o masie 2400t Zbliżony do maksymalnej masy składu z poz. 4 tabeli 1. Wyniki przedstawiono w tabeli 3 i na rys. 5 . Nastawienie „długa lokomotywa” dla krótszego skła$\mathrm{du}$ powoduje powstanie kilkukrotne mniejszych sił ściskających, niż dla nastawienia ,osobowy” utrzymując niewiele większe drogi hamowania.

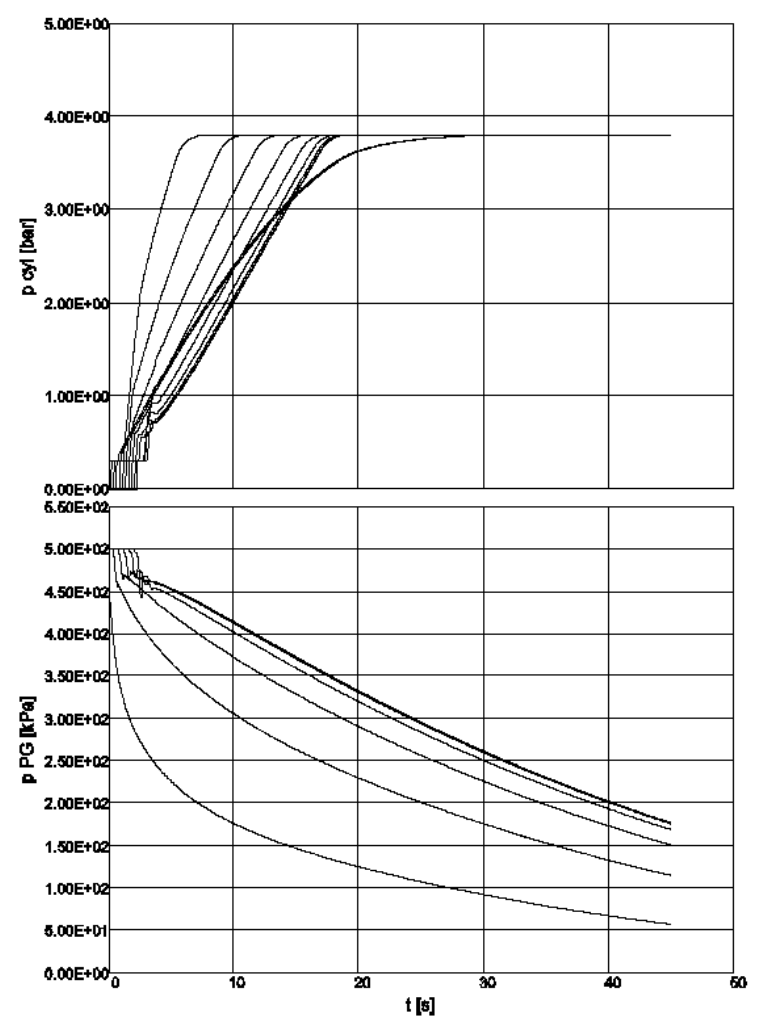

Rys. 3 Przebieg ciśnień w przewodzie głównym i cylindrach hamulcowych pociagu $700 \mathrm{~m}, 4000 \mathrm{t} \mathrm{w}$ nastawieniu , długa lokomotywa”. Przedstawiono wyniki dla co 5 wagonu 
Tabela 2.

Wyniki symulacji hamowania składu pociągu 700m, 50 wagonów o masie całkowitej 4000t

\begin{tabular}{|c|c|c|c|c|c|c|}
\hline $\mathrm{Nr}$ & $\begin{array}{c}\text { v pocz } \\
{[\mathrm{km} / \mathrm{h}]}\end{array}$ & nastawy & $\begin{array}{l}\text { droga } \\
\text { hamo- } \\
\text { wania }\end{array}$ & $\begin{array}{l}\text { Max. siła } \\
\text { między- } \\
\text { wagono- } \\
\text { wa[kN] dla } \\
\text { modelu } \\
\text { pociagu } \\
\text { sztywnego }\end{array}$ & $\begin{array}{l}\text { Max.siła międzywago- } \\
\text { nowa }[\mathrm{kN}] \text { pociąg ze } \\
\text { zderzakami ze spręży- } \\
\text { nami pierścieniowymi } \\
\text { bez luzu, } \\
\text { ściskanie/rozciagg. }\end{array}$ & $\begin{array}{c}\text { Max.siła międzywago- } \\
\text { nowa }[\mathrm{kN}] \text {, zderzaki z } \\
\text { luzem } 0,02 \mathrm{~m} \text {, ściskanie/ } \\
\text { rozciaganie }\end{array}$ \\
\hline 1 & 100 & $\begin{array}{l}\text { pojedynczy wa- } \\
\text { gon } \\
\text { tow nagłe }\end{array}$ & 818,7 & - & - & \\
\hline 2 & 100 & $\begin{array}{l}\text { pojedynczy wa- } \\
\text { gon, nast. osob, } \\
\text { nagłe }\end{array}$ & 625,1 & - & - & \\
\hline 3 & 100 & tow nagłe & 880,8 & 48,4 & 94,7 & \\
\hline 4 & 100 & osob nagłe & 743,3 & 305,4 & $473,5 /-181,7$ & $473,5 /-187,4$ \\
\hline 5 & 100 & $\begin{array}{l}\text { długa lokom, } \\
\text { nagłe }\end{array}$ & 773,4 & 183,8 & $293,3 /-122,5$ & $398,9 /-110,0$ \\
\hline \multirow[t]{2}{*}{6} & 100 & $\begin{array}{c}\text { długa lokomoty- } \\
\text { wa } \\
\text { długie odgał, } \\
\text { nagłe } \\
\end{array}$ & 856,6 & 212,8 & $278,5 /-99,0$ & $278,5 /-99,0$ \\
\hline & & $\begin{array}{c}\text { towarowy długie } \\
\text { odgał, nagłe }\end{array}$ & 895,6 & 145,2 & 151,7 & \\
\hline 7 & 100 & $\begin{array}{c}\text { towarowy, służ- } \\
\text { bowe }\end{array}$ & 1051,5 & 56,8 & 101,9 & \\
\hline 8 & 100 & $\begin{array}{l}\text { osobowy, służ- } \\
\text { bowe }\end{array}$ & 1051,5 & 57,9 & 102,3 & \\
\hline \multirow[t]{5}{*}{9} & 100 & $\begin{array}{l}\text { długa lok, służ- } \\
\text { bowe }\end{array}$ & 1052,7 & 56,9 & 102,5 & \\
\hline & 25 & długa lok, nagłe & 60,3 & 427,1 & $653,0 /-87,3$ & \\
\hline & 25 & $\begin{array}{c}\text { długa lok, długie } \\
\text { odgał, nagłe }\end{array}$ & 70,76 & 618,8 & 591,0 & \\
\hline & 25 & osobowy, nagłe & 55,33 & 639,5 & 1213,5 & \\
\hline & 25 & $\begin{array}{c}\text { osobowy, długie } \\
\text { odgat, nagłe }\end{array}$ & 63,98 & 762,4 & 971,7 & \\
\hline
\end{tabular}

Tabela 3.

Droga hamowania i maksymalne siły wzdłużne w pociągu 30-wagonowym o długości 434m i masie 2400 t

\begin{tabular}{|l|c|c|c|c|}
\hline $\mathrm{Nr}$ & $\begin{array}{l}\mathrm{v} \text { pocz } \\
{[\mathrm{km} / \mathrm{h}]}\end{array}$ & nastawy & droga ham & $\begin{array}{l}\text { siła międzywagonowe [kN] , pociag zderzaki } \\
\text { ze sprężynami pierścieniowymi bez luzu, ści- } \\
\text { skanie/rozciaganie }\end{array}$ \\
\hline 1 & 100 & towarowy, nagłe & 865,6 & 32,3 \\
\hline 2 & 100 & osobowy, nagłe & 667,27 & $195,1 /-89,1$ \\
\hline 3 & 100 & długa lokomotywa, nagłe & 708,5 & $69,6 /-126,9$ \\
\hline 4 & 25 & towarowy, nagłe & 72,6 & 68,2 \\
\hline 5 & 25 & osobowy, nagłe & 42,85 & 430,2 \\
\hline 6 & 25 & długa lokomotywa, nagłe & 48,6 & $128,9 /-301,9$ \\
\hline
\end{tabular}

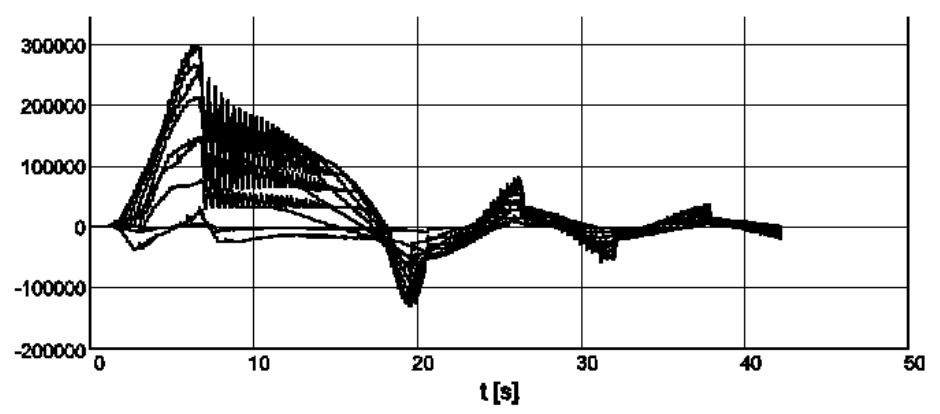

Rys. 4. Siły wzdłużne w pociągu 700m, 4000t w nastawieniu ,długa lokomotywa" ze zderzakami ze sprężynami pierścieniowymi bez luzu, hamowanie nagłe ze $100 \mathrm{~km} / \mathrm{h}$ 


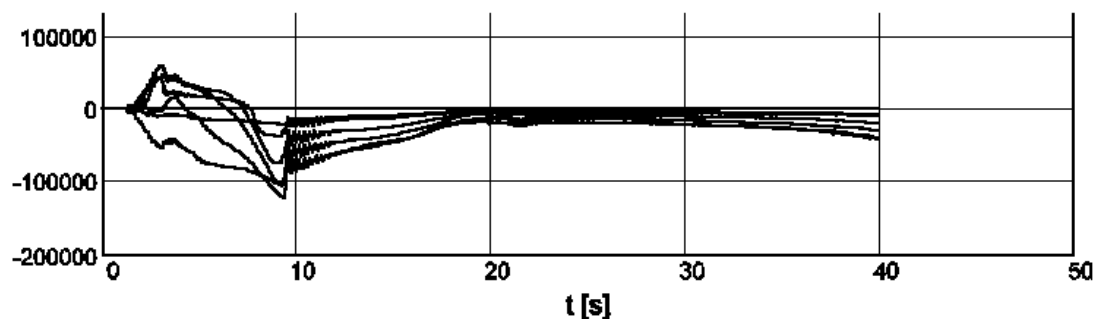

$t[s]$

Rys. 5. Siły wzdłużne w symulacji hamowania składu pociagu , 30-wagonowym o długości $434 \mathrm{~m}$, masie całkowitej 2400t hamowanego z $100 \mathrm{~km} / \mathrm{h}$, nastawienie „długa lokomotywa". Wyniki dla co 5 wagonu

\section{Podsumowanie}

Zaprezentowane bardzo skrótowo analizy pozwalają stwierdzić, że maksymalne długość pociagu $700 \mathrm{~m}$ dla nastawienia „długa lokomotywa” jest prawidłowa. Dla dłuższych pociagów (nie prezentowanych w artykule) z powodu spowolnienia zjawisk pneumatycznych (opóźnienie reakcji hamulca $\mathrm{w}$ końcu pociagu) stosowane tej nastawy nie byłoby celowe. Korzyści ze stosowania nastawy „długa lokomotywa” dla pociągów krótszych są bardziej ewidentne (tab. 3 i rys. 5). Pozwala to na uzyskanie niewielkich sił wzdłużnych przy tylko nieznacznym wydłużeniu drogi hamowania w stosunki do nastawienia „osobowy” i bardzo korzystnym zbliżonym do symetrycznego rozłożeniu sił wzdłużnych.

Zaletą omawianego nastawienia jest opóźnienie wzrostu siły hamowania w pierwszych wagonach w porównaniu z resztą pociągu powodujące powstanie sił rozciagających w przedniej części pociagu zamiast ściskających, co wywołuje proporcjonalne zmniejszenie maksymalnych sił ściskających

Znacznemu skróceniu ulega droga hamowania Jest ona bardziej ewidentna dla pociagu krótszego (np. 30 wagonów), niż dla pociągu 50 wagonowego ( maksymalna wielkość pociągu z nastawieniem ,długa lokomotywa")

\section{Literatura}

[1] Piechowiak T., Badanie i modelowanie procesów zachodzacych $w$ ukladach pneumatycznych pociagów. Politechnika Poznańska, Rozprawy Nr 414, 2007, s. 155. Rozprawa habilitacyjna

[2] Piechowiak T., Pneumatic train brake simulation method. Vehicle System Dynamics, V. 47, Issue 12, December 2009, pp. 1473 - 1492.

[3] Piechowiak T., Verification of the pneumatic railway brake models. Vehicle System Dynamics, Volume 48, Issue 3, March 2010, pp. 283 - 299

[4] Piechowiak T., Wplyw wybranych parametrów układu hamulcowego na bezpieczeństwo jazdy pociagów towarowych, Politechnika Poznańska 1985, $s$, . Praca doktorska

[5] Schmidt S.,Heine Ch.,Nock M. Walter M., Beherrschung von Längskräften in sehr langen Güterzügen. ZEVrail 133(2009), pp. 358-364

[6] Instrukcja obstugi $i$ utrzymania $w$ eksploatacji hamulców taboru kolejowego. PKP CARGO, ze zmianami w 2009 r. 